\title{
Meningkatkan Kesediaan Merawat Orang Dengan HIV/AIDS (ODHA) Pada Perawat Puskesmas Dengan Menggunakan Metode $A$ Brief Intervention
}

\author{
Ari Athiutama ${ }^{a}$, Arina Widya Murni ${ }^{b}$, Tasmanc \\ ${ }^{a}$ Fakultas Keperawatan, Universitas Andalas, Padang, 25163, Indonesia \\ ${ }^{b}$ Fakultas Kedokteran, Universitas Andalas, Padang, 25163, Indonesia \\ 'Jurusan Keperawatan, Poltekkes Kemenkes Padang, Padang, 25146, Indonesia \\ e-mail korespondensi: ariathiutama96@gmail.com
}

\begin{abstract}
HIV/AIDS is a problem for health workers, especially nurses, which results in negative things such as the stigma of discrimination in health services so the treatment of PLWHA is being not optimal. The purpose of this study is to determine the effect of a brief intervention on the public health center nurses on the willingness to treat PLWHA. The design of this study is the Quasy Experiment Pre-Post Test With Control Group the sample is 48 nurses consisting of 24 nurses in the intervention group and 24 nurses in the control group selected by using total sampling techniques. Data were collected by using a nursing willingness questionnaire (NWQ) that was translated into Indonesian languages and analyzed using the paired sample t test and independent samples t test. The results showed there were differences in the willingness to care on pre and post-test intervention group ( $p$ value $=0.001$ ) and there is difference in the willingness to care the intervention group and the control group ( $p$ value $=0.027)$. The conclusion of a brief intervention method is effective in increasing willingness to treat PLWHA on public health center nurses. A brief intervention method as an innovation method that can be used in public health center to share information, especially regarding willingness to treat PLWHA.
\end{abstract}

Keywords: A Brief Intervention, HIV/AIDS, Nurse, Willingness to Care

\begin{abstract}
Abstrak
HIV/AIDS menjadi masalah bagi para tenaga kesehatan khususnya perawat yang mengakibatkan terjadinya hal negatif seperti stigma diskriminasi dalam pelayanan kesehatan sehingga perawatan pada ODHA menjadi tidak optimal. Tujuan penelitian ini yaitu untuk mengetahui pengaruh dari a brief intervention pada perawat puskesmas terhadap kesediaan merawat ODHA. Desain penelitian ini yaitu Quasy Experiment Pre-Post Test With Control Group dengan jumlah sampel 48 perawat yang terdiri dari 24 perawat kelompok intervensi dan 24 perawat kelompok kontrol yang dipilih dengan menggunakan teknik total sampling. Data dikumpulkan dengan menggunakan kuisioner nursing willingness questionnaire (NWQ) yang telah dialih bahasa dan dianalisis menggunakan uji paired sample $t$ test dan independent samples $t$ test. Hasil penelitian menunjukkan bahwa adanya perbedaan nilai kesediaan merawat pre test dan post test pada kelompok intervensi (nilai $p$ value $=0,001$ ) dan adanya perbedaan kesediaan merawat kelompok intervensi dan kelompok kontrol (nilai $p$ value $=0,027$ ). Kesimpulan metode a brief intervention ini efektif dalam meningkatkan kesediaan merawat ODHA pada perawat puskesmas. Metode a brief intervention sebagai metode inovasi yang dapat digunakan puskesmas untuk berbagi informasi khususnya mengenai kesediaan merawat ODHA.
\end{abstract}

Kata kunci: A Brief Intervention, HIV/AIDS, Perawat, Kesediaan Merawat

\section{PENDAHULUAN}

Human Immunodeficiency Virus (HIV) merupakan virus yang menyebabkan penyakit Acquired Immunodeficiency Syndrome (AIDS) dimana penyakit ini menyerang sel darah putih yaitu CD4 sehingga rusaklah sistem kekebalan tubuh pada manusia tersebut (Rohan et al., 2017). Sedangkan Acquired Immuno Deficiency Syndrome (AIDS) adalah penyakit yang ditandai dengan gejala melemahnya sistem kekebalan tubuh yang diakibatkan oleh infeksi dari virus HIV (Kemenkes RI, 2018). 
Tenaga kesehatan bertanggung jawab dalam memberikan pelayanan kepada Orang dengan HIV/AIDS (ODHA). Perawat merupakan salah satu tenaga kesehatan yang harus memberikan pelayanan profesional kepada pasien secara etis dan aman, namun kenyataannya lebih banyak perawat memiliki sikap negatif dalam melakukan perawatan pada pasien HIV/AIDS $(59,5 \%)$ (Husna \& Fitriani, 2016). Sikap negatif yang dimaksud salah satunya yaitu kurangnya kesediaan perawat untuk merawat ODHA. Kesediaan perawat dalam memberikan perawatan pada pasien ODHA masih sangat kurang, hal ini dipengaruhi beberapa faktor yaitu salah satunya rasa takut akan tertular HIV/AIDS.

Dari hal tersebut, sangat penting mengatasi masalah perawat secara efektif (Koto \& Maharaj, 2016). Mahathir et al., (2020) mengatakan banyak informasi mengenai HIV/AIDS yang dapat diakses dan ini merupakan suatu tanda dari keberhasilan untuk melawan HIV/AIDS dan harus dipertahankan dengan mengoptimalkan pilihan metode penyampaian informasi yang baik.

A brief intervention adalah salah satu hal yang dapat dilakukan dalam memperbaiki kesediaan perawat untuk merawat ODHA. A brief intervention merupakan percakapan yang bersifat dipandu dan disampaikan dengan gaya yang memotivasi sehingga dapat membedakan a brief intervention ini dengan metode pemberian informasi dasar pada umumnya, meskipun sekedar memberikan informasi dasar dan memberikan bahan tertulis serta dibawa pulang, hal tersebut merupakan bagian dari a brief intervention (South Eastern Health and Social Care Trust, 2015).

A brief intervention ini umumnya ditawarkan kepada orang yang belum mencari bantuan tetapi telah diidentifikasi masalah yang dihadapinya (Rodgers, 2018). Tujuan dari a brief intervention adalah untuk mendukung orang tersebut agar memikirkan perilakunya serta membantu mereka untuk membuat hubungan antara perilaku mereka dengan segala risiko dan bahaya yang berkaitan dengan perilaku tersebut (Raki, 2012).

A brief intervention yang dilakukan oleh Athiutama et al., (2020) menunjukkan perubahan sikap negatif, dimana nilai pre test stigma diskriminasi sebesar 59.21 menurun pada post test menjadi 46.46. Selanjutnya penelitian Shah et al., (2014) melakukan penelitian dengan memberikan beberapa intervensi berupa paparan power point selama 45 menit dan responden diberi handout dari slide serta adanya waktu untuk diskusi tanya jawab, penelitian ini menunjukkan hasil bahwa intervensi yang dilakukan memiliki potensi baik untuk menurunkan stigma diskriminasi. Sedangkan penelitian yang dilakukan oleh Frain (2017) memberikan intervensi dengan mengundang pembicara yaitu orang yang berpengalaman bekerja dalam merawat ODHA, sebelum bertemu dengan pembicara peserta diperlihatkan sebuah video tentang bagaimana epidemi dari HIV/AIDS serta bagaimana penularannya, hasil dari intervensi membuat dampak yang luar biasa untuk kesediaan merawat ODHA.

\section{METODE}

Penelitian ini menggunakan desain kuantitatif dengan rancangan Quasi Eksperimen Pre-Post Test With Control Group dengan tujuan meningkatkan kesediaan merawat ODHA pada perawat puskesmas. Keterangan lolos kaji etik didapatkan pada Fakultas Kedokteran Universitas Andalas pada tanggal 06 Desember 2019 (No: 637/KEP/FK/2019).

Perawat puskesmas yang belum memiliki care support treatment (CST) dijadikan responden pada kelompok intervensi dan perawat puskesmas yang memiliki CST dijadikan responden pada kelompok kontrol. Pengambilan sampel dengan total sampling dengan jumlah sebanyak 48 perawat yang memenuhi kriteria inklusi dan eksklusi, dimana 24 
perawat kelompok intervensi dan 24 perawat kelompok kontrol.

Data dikumpulkan dengan menggunakan kuisioner nursing willingness questionnaire (NWQ) dari Lioznov et al., (2015) yang telah dialih bahasa serta dilakukan uji validitas dan reliabilitas oleh peneliti, data dianalisis menggunakan uji paired sample t test dan independent samples $t$ test.

A brief intervention terdiri dari empat media yaitu power point, handout, narasumber dan audiovisual. Pada awal pelaksanaan, responden terlebih dahulu mengisi inform consent dan kemudian diminta untuk bergabung dalam whatsapp group sesuai puskesmas masing-masing dan kemudian responden mengisi kuisioner pre test. Selama proses intervensi, responden diberikan a brief intervention dan dilakukan sebanyak dua kali pertemuan. Pertemuan pertama, diberikan intervensi mengenai informasi dasar tentang HIV/AIDS dengan media power point, audiovisual, kemudian responden diberikan handout dan diakhir pertemuan dibuka sesi tanya jawab. Selanjutnya, pada pertemuan kedua dilakukan pada hari berikutnya, responden diberikan intervensi mengenai pengalaman dalam merawat ODHA dengan media audiovisual, narasumber, kemudian responden diberikan handout, dan diakhir pertemuan dibuka sesi tanya jawab.

Setelah selesai pemberian intervensi, peneliti mengingatkan responden melalui whatsapp group untuk membaca materi yang diberikan (handout ataupun catatan responden) setiap harinya hingga hari ketujuh dan kemudian dilakukan post test pada hari kedelapan.

\section{HASIL}

Hasil pada penelitian ini dapat dilihat pada uraian dibawah ini :

Tabel 1. Perbedaan Kesediaan Merawat Pre Test dan Post Test Pemberian A Brief Intervention Pada Perawat Puskesmas Terhadap ODHA Pada Kelompok Intervensi dan Kelompok Kontrol

\begin{tabular}{|c|c|c|c|c|c|}
\hline Kelompok & $\begin{array}{c}\text { Kesediaan } \\
\text { Merawat }\end{array}$ & $\mathbf{N}$ & Mean & $\Delta$ & $\begin{array}{c}\mathbf{P} \\
\text { Value }\end{array}$ \\
\hline \multirow{2}{*}{ Intervensi } & Pre Test & 24 & 51.33 & \multirow{2}{*}{10.55} & \multirow{2}{*}{0.001} \\
\hline & Post Test & 24 & 61.88 & & \\
\hline \multirow{2}{*}{ Kontrol } & Pre Test & 24 & 54.92 & \multirow{2}{*}{0.83} & \multirow{2}{*}{0.497} \\
\hline & Post Test & 24 & 55.75 & & \\
\hline
\end{tabular}

Tabel 1 menunjukkan hasil analisis pada kelompok intervensi menggunakan uji paired sample t test adalah 0.001 (nilai $\mathrm{p}$ value $<0,05$ ) artinya adanya perbedaan nilai kesediaan merawat pre test dan post test pada kelompok intervensi. Hasil lain yang didapatkan adalah nilai mean pre test adalah 51.33 dan nilai post test adalah 61.88 dengan selisih yang didapatkan yaitu 10.55 .

Tabel 2 Perbedaan Kesediaan Merawat Perawat Puskesmas Setelah Pemberian A Brief Intervention Pada Kelompok Intervensi dan Kelompok Kontrol

\begin{tabular}{ccccc}
\hline Kelompok & $\begin{array}{c}\text { Kesediaan } \\
\text { Merawat }\end{array}$ & N & Mean & $\begin{array}{c}\text { P } \\
\text { Value }\end{array}$ \\
\hline Intervensi & Post Test & 24 & 61.88 & 0.027 \\
\cline { 1 - 4 } Kontrol & Post Test & 24 & 54.75 & \\
\hline
\end{tabular}

Tabel 2 menunjukkan nilai rata-rata post test kesediaan merawat pada kelompok intervensi adalah 61.88 dan nilai rata-rata post test kesediaan merawat pada kelompok kontrol adalah 54.75. Maka dari hasil tersebut dapat diartikan adanya perbedaan nilai rata-rata kesediaan merawat post test kelompok intervensi dan kelompok kontrol. Nilai signifikan 0.027 
(nilai $\mathrm{p}$ value $<0,05)$ dengan demikian dapat disimpulkan adanya pengaruh $a$ brief

\section{PEMBAHASAN}

Perbedaan kesediaan merawat pre test dan post test pemberian a brief intervention pada perawat puskesmas terhadap ODHA pada kelompok intervensi dan kelompok kontrol.

Kesediaan merawat merupakan sikap perawatan terhadap dukungan emosional, fisik dan fasilitas perawatan untuk ODHA. Penelitian yang dilakukan Ishimaru et al., (2017) mengatakan bahwa mayoritas perawat menyatakan keinginan untuk merawat ODHA $(55,8 \%)$ lebih rendah jika dibandingkan dengan kesediaan ketika merawat $\mathrm{HBV} / \mathrm{HCV}$ (73,3\%), kesediaan untuk merawat ODHA berkaitan dengan usia dan kemampuan melindungi diri dari infeksi. Tazakori et al., (2017) melakukan penelitian yang menunjukkan bahwa perawat mengalami tantangan, ketakutan, dan stres yang berat saat menghadapi ODHA dan mereka menggunakan perilaku yang protektif dalam memberikan perawatan.

Berdasarkan dari hal diatas, untuk meningkatkan upaya kesediaan merawat ODHA, peneliti mengharapkan penerapan pemberian informasi tambahan mengenai perawatan pada ODHA yang lebih mendalam dan teratur menggunakan metode dan berbagai media seperti audiovisual, handout serta mengundang orang yang lebih berpengalaman mengenai HIV/AIDS sehingga hasilnya dapat lebih efektif dan lebih efisien.

Kesediaan merawat yang kurang ditandai dengan kurangnya pengetahuan serta adanya stigma diskriminasi sehingga perlu adanya pembaruan informasi mengenai perawatan ODHA. Intervensi yang dilakukan $\mathrm{He}$ et al., (2016) dapat intervention terhadap kesediaan merawat perawat.

meningkatkan pengetahuan perawat dengan nilai $\mathrm{p}$ value 0.000 dan kesediaan perawat untuk merawat para ODHA juga mengalami peningkatan. Gonzalez et al., (2020) telah merekomendasikan a brief intervention dengan cara yang terstruktur sebagai metode dasar dalam memberikan pendidikan pada perawat dengan waktu yang relatif singkat.

Kesediaan untuk merawat merupakan hal yang mutlak harus dimiliki sebagai perawat professional karena bila hal tersebut tidak dimiliki maka akan melanggar hak dari penderita. Hasil dari penelitian menunjukkan ada peningkatan kesediaan perawat untuk merawat ODHA menjadi lebih baik. Perbedaan nilai ratarata kesediaan merawat pre test dan post test pada kelompok intervensi terjadi dikarenakan adanya perlakuan yang diberikan peneliti yaitu a brief intervention.

Berkaitan dengan hal tersebut, peneliti berharap agar penyedia program dan pihak terkait untuk dapat memberikan dan berbagi informasi dengan tenaga kesehatan lain khususnya perawat sehingga dapat meningkatkan kesediaan merawat ODHA, konsumsi ARV terkontrol dan penularan dari HIV/AIDS ke orang lain dapat dicegah dan diminimalisir.

Perbedaan kesediaan merawat perawat puskesmas setelah pemberian $a$ brief intervention pada kelompok intervensi dan kelompok kontrol.

Terdapatnya peningkatan serta perbedaan nilai rata-rata kesediaan merawat menurut pendapat peneliti yaitu dikarenakan kelompok intervensi diberikan a brief intervention dengan berbagai media berbeda dengan kelompok kontrol yang 
tidak ada perlakuan sama sekali. Hal ini menunjukkan bahwa a brief intervention dapat meningkatkan kesedian perawat puskesmas merawat ODHA.

Asuhan keperawatan yang efektif berasal dari orang yang terlatih dan hati yang penuh kasih sayang merupakan kunci intervensi dalam perawatan HIV/AIDS, ketakutan dalam merawat dan juga saat berurusan dengan ODHA sering kali menghambat dalam melakukan perawatan kesehatan (Adhikari et al., 2016). Temuan penelitian yang dilakukan oleh Okpala et al., (2017) mengatakan bahwa faktor utama yang mempengaruhi sikap perawat dalam merawat ODHA adalah rasa takut tertular HIV/AIDS (nilai $\mathrm{p}$ value 0.000), oleh karena itu perawat harus dilengkapi alat pelindung diri serta pelatihan dalam layanan HIV/AIDS, ini akan meningkatkan kualitas perawatan pada ODHA.

Penelitian dari Richter et al., (2012) melaporkan bahwa a brief intervention dapat dilakukan pada konteks meningkatkan perawatan kesehatan pada anak dan secara tidak langsung intervensi ini melibatkan orang tua dan keluarga dalam memberikan asuhan keperawatan pada anak di lingkungan dengan kejadian HIV/AIDS yang tinggi, nilai rata-rata pre test sebesar 3.10 meningkat pada post test sebesar 3.65 dengan nilai $\mathrm{p}$ value 0.001 . MacHowska et al., (2020) melakukan intervensi berupa pelatihan pada perawat dimana terjadi perbaikan nilai pada post test yang signifikan terlihat pada pengetahuan dan sikap di kelompok perawat maupun kelompok mahasiswa keperawatan.

Dari hasil yang ditemukan peneliti, teori serta penelitian sebelumnya maka peneliti berharap puskesmas dapat menentukan jadwal rutin untuk berbagi informasi dengan rekan terutama perawat tentunya dengan melibatkan media yang menarik sehingga kesediaan merawat ODHA meningkat, konsumsi ARV terkontrol dan penularan dari HIV/AIDS ke orang lain dapat dicegah dan diminimalisir.

Pengetahuan dan stigma diskriminasi yang baik akan mempengaruhi kesediaan perawat untuk merawat ODHA, pemberian perlakuan metode a brief intervention memberikan hasil yang efektif dalam meningkatkan perawatan pada ODHA. Penelitian sebelumnya dengan perlakuan yang berbeda menunjukkan manfaat terhadap kesediaan perawat untuk merawat ODHA dilakukan pada sampel mahasiswa kesehatan dan tenaga kesehatan secara keseluruhan.

\section{KESIMPULAN}

Kesimpulan dalam penelitian ini adalah kesediaan perawat dalam merawat ODHA masih dapat ditingkatkan, sehingga pelayanan kesehatan terhadap ODHA menjadi lebih optimal. Salah satu upaya yang efektif untuk dilakukan yaitu a brief intervention. Dengan melakukan a brief intervention secara rutin, dapat meningkatkan kesediaan merawat ODHA pada perawat puskesmas.

\section{UCAPAN TERIMA KASIH}

Peneliti mengucapkan banyak terima kasih kepada pihak puskesmas yang memberikan izin untuk melakukan penelitian serta peneliti juga berterima kasih banyak kepada semua responden yang telah berperan aktif dalam kegiatan penelitian ini.

\section{DAFTAR PUSTAKA}

Adhikari, K., Gupta, N., Koshy, A. K., Jain, V. M., Ghimire, A., Jnawali, K., \& Paneru, D. P. (2016). Knowledge and Attitude towards HIV/AIDS amongst Nursing Students in Nepal. 
NERS: Jurnal Keperawatan, Volume 16, No. 2, Oktober 2020, (Hal. 54-60)

SAARC Journal of Tuberculosis, Lung Diseases and HIV/AIDS, 12(1), 8-13. https://doi.org/10.3126/saarctb.v12i1. 15936

Athiutama, A., Murni, A. W., \& Tasman. (2020). A Brief Intervention Untuk Menurunkan Stigma Diskriminasi Perawat Puskesmas Terhadap Orang Dengan HIV/AIDS. Jurnal Keperawatan, 12(1), 1-6. https://doi.org/https://doi.org/10.3258 3/keperawatan.v12i1.687

Frain, J. A. (2017). Preparing Every Nurse to Become an HIV Nurse. Nurse Education Today, 48, 129-133. https://doi.org/10.1016/j.nedt.2016.10 .005

Gonzalez, Y., Kozachik, S. L., Hansen, B. R., Sanchez, M., \& Finnell, D. S. (2020). Nurse-Led Delivery of Brief Interventions for At-Risk Alcohol Use: An Integrative Review. Journal of the American Psychiatric Nurses Association, 26(1), 27-42. https://doi.org/10.1177/10783903198 72536

He, L., Lu, Z., Huang, J., Zhou, Y., Huang, J., Bi, Y., \& Li, J. (2016). An integrated intervention for increasing clinical nurses' knowledge of HIV/aids-related occupational safety. International Journal of Environmental Research and Public Health, 13(11). https://doi.org/10.3390/ijerph1311109 4

Husna, C., \& Fitriani, I. (2016). Kompetensi Perawat Pelaksana Dalam Merawat Pasien Hiv/Aids. Idea Nursing Journal, 7(1), 70-77.

Ishimaru, T., Wada, K., Hoang, H. T. X., Bui, A. T. M., Nguyen, H. D., Le, H., \& Smith, D. R. (2017). Nurses' willingness to care for patients infected with HIV or hepatitis B / C in Vietnam. Environmental Health and
Preventive Medicine, 22(1), 1-7. https://doi.org/10.1186/s12199-0170614-y

Kemenkes RI. (2018). Data dan Informasi Profil Kesehatan Indonesia.

Koto, M. V., \& Maharaj, P. (2016). Difficulties facing healthcare workers in the era of AIDS treatment in Lesotho. Sahara J, 13(1), 53-59. https://doi.org/10.1080/17290376.201 6.1179588

Lioznov, D., Nikolaenko, S., Välimäki, M., Laakkonen, L., Kylmä, J., Polukova, M., Suominen, T., \& Lipiäinen, L. (2015). Willingness to take care of HIV positive people: Responses from Russian nursing students. Nordic Journal of Nursing Research, 35(2), 71-76. https://doi.org/10.1177/01074083145 60323

MacHowska, A., Bamboria, B. L., Bercan, C., \& Sharma, M. (2020). Impact of HIV-related stigma-reduction workshops' on knowledge and attitude of healthcare providers and students in Central India: A pre-test and post-test intervention study. $B M J$ Open, 10(4), 1-10. https://doi.org/10.1136/bmjopen2019-033612

Mahathir, M., Wiarsih, W., \& Permatasari, H. (2020). How Do People Living With HIV Acquire HIV Related Information: A Qualitative Evaluation of Jakarta Setting. 15(3).

Okpala, P. U., Uwak, R., Nwaneri, A. C., Onyiapat, J., Emesowum, A., Osuala, E. O., \& Adeyemo, F. O. (2017). Nurses' knowledge and attitude to the care of HIV/AIDS patients in South East, Nigeria. International Journal Of Community Medicine And Public Health, 4(2), 547. https://doi.org/10.18203/23946040.ijcmph20170289 
NERS: Jurnal Keperawatan, Volume 16, No. 2, Oktober 2020, (Hal. 54-60)

Raki, M. (2012). Brief intervention guide addressing risk and harm related to alcohol, tobacco, other drugs and gambling. 1-40.

Richter, L. M., Rochat, T. J., Hsiao, C., \& Zuma, T. H. (2012). Evaluation of a Brief Intervention to Improve the Nursing Care of Young Children in a High HIV and AIDS Setting. Nursing Research and Practice, 2012, 1-8. https://doi.org/10.1155/2012/647182

Rodgers, C. (2018). Brief Interventions for Alcohol and Other Drug Use. Australian Prescriber, 41(4), 117121.

https://doi.org/10.18773/austprescr.20 18.031

Rohan, H. H., Setyowati, A., Herdyana, E., Komariyah, S., \& Agustina, E. (2017). Kesehatan Reproduksi: Pengenalan Penyakit Menular
Reproduksi dan Pencegahan (1st ed.). Intimedia.

Shah, S. M., Heylen, E., Srinivasan, K., Perumpil, S., \& Ekstrand, M. L. (2014). Reducing HIV Stigma Among Nursing Students: A Brief Intervention. Western Journal of Nursing Research, 36(10), 13231337. https://doi.org/10.1177/01939459145 23685

South Eastern Health and Social Care Trust. (2015). A pocket guide to brief intervention and behaviour change.

Tazakori, Z., Moshfeghi, S., \& Karimollahi, M. (2017). Nurse's Experiences of Caring for Patients with HIV/AIDS in Ardabil, Iran. HIV: Current Research, 2(1), 2-5. https://doi.org/10.4172/25720805.1000118 